\title{
The Relationship Between Instructor Servant Leadership Behaviors and Satisfaction with Instructors in an Online Setting
}

\author{
Faris George Sahawneh \\ West Kentucky Community and Technical College \\ Lorraine T. Benuto \\ University of Nevada, Reno
}

\begin{abstract}
Servant leadership has the potential to improve student satisfaction within online learning. However, the relationship between servant leadership and student satisfaction in an online environment had not yet been understood at the level of the individual instructor. The purpose of this quantitative, correlational study was to evaluate the relationship between online students' perception of their instructor's servant leadership style and the student's satisfaction with the online instructor. We selected 155 online students at a major community college in the southcentral United States to complete the Servant Leadership Questionnaire (SLQ) and the Student Evaluation of Teaching (SET) survey online. We examined the relationships between each of the five facets of perceived servant leadership style (altruistic calling, emotional healing, wisdom, persuasive mapping, and organizational stewardship) and student satisfaction. The results of the Spearman's correlations showed a strong positive correlation between all servant leadership behaviors and student satisfaction, $p<.001$. A multiple linear regression analysis showed that the combination of altruistic calling, persuasive mapping, and wisdom strongly predicted student satisfaction with the instructor, $F(3,151)=83.8, p<.001, R^{2}=.63$. The results of this study have filled a gap in the literature on the relationship between online student satisfaction and individual servant leadership behaviors. We recommend future research to investigate servant leadership in relationship to online learning at 4 -year public, for-profit, and private institutions.
\end{abstract}

Keywords: servant leadership, student satisfaction, altruistic calling, emotional healing, wisdom, persuasive mapping, organizational stewardship

Sahawneh, F.G. \& Benuto, L.T. (2018). The relationship between instructor servant leadership behaviors and satisfaction with instructors in an online setting. Online Learning, 22(1), 107-129. doi:10.24059/olj.v22i1.1066 


\section{The Relationship Between Instructor Servant Leadership Behaviors and Satisfaction with Instructors in an Online Setting}

In $2014,51 \%$ of U.S. students enrolled in institutions of higher education had taken at least one online course (Allen \& Seaman, 2016). Despite the many benefits of online learning (Bowen, 2013; Cole, Shelley, \& Swartz, 2014; Jones, Everard, \& McCoy, 2011; Woodall, Hiller, \& Resnick, 2014), student persistence and retention in the online environment remains low (Sorensen \& Donovan, 2017; Xu \& Jaggars, 2011). Increased student satisfaction is related to increases in student persistence (Hart, 2012; Joo, Joung, \& Kim, 2013; Schreiner \& Nelson, 2013). When instructors show empathy and caring (Hazel et al., 2014; Ladyshewsky, 2013); express personal consideration; and offer intellectual stimulation, motivation, and inspiration (Bogler, Caspi, \& Roccas, 2013), student satisfaction, retention, and success increase (Kranzow, 2013; Gomez, 2013; Joo et al., 2013). Many of these instructor characteristics are consistent with the emergent servant leadership theory (Jacobs, 2011; Noland \& Richards, 2015; van de Bunt-Kokhuis \& Weir, 2013).

A servant leader is a leader who places other people's needs, goals, and wellbeing above his or her own in order to produce a positive transformation among followers (Blanchard \& Miller, 2007; Barnabas et al., 2010; Greenleaf, 1978; Letizia, 2014). The relationship between students and instructors in an online course is similar to the leader-follower relationship observed in organizational settings (Bolkan \& Goodboy, 2011; Bogler et al., 2013). What distinguishes online learning from other traditional learning modalities is that the constraints of a set time and a set place affect the online learning milieu weakly or not at all (Nayamboli, 2014). In the online classroom, instructors act as leaders (Garcia, 2015), and their style of leadership may influence their followers, who are the students (Noland \& Richards, 2015; Pounder, 2014).

Servant leadership may be a good fit for online learning as online learners face unique challenges such as social isolation, persistence, and high attrition rates (Johnson \& Vishwanath, 2011; Huber, 2014; Mariano, 2013; Reed \& Swanson, 2014). Servant leadership may benefit online learners by means of emotional healing, wisdom, persuasive mapping, commitment to the growth and empowerment of others, offers of feedback, and commitment to building a community of learners (Barbuto \& Wheeler, 2006; Huber, 2014; Steele, 2010). These instructor behaviors may affect student satisfaction (Huber, 2014), thereby increasing student retention and engagement (Lorenzo, 2012; Noland \& Richards, 2015; Schreiner \& Nelson, 2013; Cole et al., 2014). However, most existing research on servant leadership in higher education has focused on measuring the organizational level of servant leadership rather than on examining servant leadership characteristics within individual instructors (Jacobs, 2011; Nyamboli, 2015; Padron, 2012).

University instructors committed to classroom excellence are critical to the success of any institution of higher education (Leroy, Palanski, \& Simons, 2012). Instructors face challenges that stem from the expectations of administrators, students, and accrediting agencies and from the demands of academic research (Jacobs, 2011). Nonetheless, committed servant leadership instructors willingly undertake these challenges to achieve the desired outcome: changed lives and satisfied students (Greenleaf, 1982).

A fundamental element in the learning process is the teacher-student relationship (Noland \& Richards, 2015; van de Bunt-Kokhuis \& Weir, 2013). This relationship, which is initiated and fostered by the teachers, mirrors the leader-follower relationship found in an organizational setting (Bolkan \& Goodboy, 2011; Bogler et al., 2013; Letizia, 2014; Noland \& Richards, 2015). Healthy 
and trusting relationships between teachers and students in the classroom leads to improvements and progress for the students (Noland \& Richards, 2015; Reed \& Swanson, 2014; Ren, 2010). Building such relationships begins with the teacher's desire to serve the students. The quality of this service is demonstrated when students grow to be healthier and wiser and when the students themselves become servants of others (Greenleaf, 1977).

Most of the studies of the relationship between servant leadership and student satisfaction have focused on the organizational level of servant leadership (Jacobs, 2011; Nyamboli, 2014; Padron, 2012). No studies to date have involved an examination of servant leadership at the level of the individual leader in relationship to online student satisfaction. However, both the organizational level and the individual level of servant leadership must be considered (Covey, 1998; Irving, 2005). Focusing on servant leadership at the individual level provides an opportunity to examine key individual characteristics of servant leadership (Covey, 1998; Noland \& Richards, 2015). Furthermore, to achieve servant leadership at the organizational level, a critical mass of people within the organization must first begin the individual practice of servant leadership (Irving, 2005; Laub, 1999).

The current study provided the opportunity to examine five key individual characteristics of servant leadership and online student satisfaction. These characteristics of servant leadership are (a) altruistic calling, (b) emotional healing, (c) wisdom, (d) persuasive mapping, and (e) organizational stewardship (Barbuto \& Wheeler, 2006). These five theoretical dimensions were based on an examination of the seminal works of Greenleaf (1977) and Spears (1998) and then conceptualized in the Servant Leadership Questionnaire (SLQ; Barbuto \& Wheeler, 2006). A better understanding of the relationship between individual instructor leadership behaviors and student satisfaction will help university managers, instructors, and other stakeholders design more effective trainings designed to foster leadership qualities in online instructors. These leadership qualities can improve online-student satisfaction (Bogler et al., 2013; Nyamboli, 2014; Huber, 2014) and thereby improve student persistence (Croxton, 2014; Kranzow, 2013).

The purpose of this study was to evaluate the statistical relationship between students' perception of their instructor's servant leadership style and the student's satisfaction with the online instructor. A brief literature review is presented, followed by a discussion of the method used. The results of the study are then presented, followed by a discussion of the findings and a conclusion.

\section{Review of Related Literature}

Online classrooms are replacing the traditional on-campus classroom settings at an increasingly rapid rate (Allen \& Seaman, 2016). Just as students are making changes to adapt to this virtual learning modality, educational leaders must also make the changes necessary to ensure student satisfaction with the online environment (Cole et al., 2014; Croxton, 2014; Huber, 2014; Nyamboli, 2014). An improved understanding of leadership behaviors of individual instructors will help university managers, instructors, and other stakeholders to design effective trainings to foster leadership qualities in educators teaching in the online environment. Improved leadership behaviors have the potential to improve student satisfaction and achievement in online education (Kranzow, 2013; Joo et al., 2011). Servant leadership behaviors among online instructors may exercise a positive influence on online education (Huber, 2014; Nyamboli, 2014; Reed \& Swanson, 2014; van de bunt-Kokhuis \& Sultan, 2012). 
Based on the writings of Greenleaf (1977, 1978, 1982), Spears (1998) identified 10 behaviors of servant leadership. These components were the first distillation of the ideas of Greenleaf into a model that described servant leadership in precise terms (van Dierendonck, 2011). The 10 characteristics were listening, empathy, healing, awareness, persuasion, conceptualization, foresight, stewardship, commitment to the growth of people, and building a community.

Spears (2005) was able to crystalize Greenleaf's $(1977,1978,1982)$ ideas, but did not continue to provide measurement tools to test servant leadership theory empirically. Therefore, researchers were unable to conduct valid, reliable empirical studies based on these qualities (Parris \& Peachy, 2013). According to Spears (1998), all these values were needed so that each servant leader would have the tools necessary to build a viable community for a large number of people and thus lead the way by showing a commitment to the well-being and growth of the members of the community. Applying these behaviors, values, and principles of servant leadership is particularly necessary in higher education (Huber, 2014; Nyamboli, 2014; Wheeler, 2012).

Styles of leadership commonly found in higher education, such as transactional and laissezfaire leadership, are limited in their leadership potential. These styles are leader-centered and do not empower others to be involved in working together for the common good (Wheeler, 2012). There is a need to recapture the vision and passion that ignited the early excitement about becoming servants in the field of education (Guillaume, Honeycutt, \& Savage-Austin, 2013; Letizia, 2014; Shaw \& Newton, 2014). This leadership gap in higher education can be filled by a leadership style that will transform educational institutions and thus restore the public confidence in higher education, foster long-term commitments, and nurture a work environment in which people thrive as they provide service to others (Letizia, 2014; Noland \& Richards, 2015; Paul \& Fitzpatrick, 2015; Shaw \& Newton, 2014; Wheeler, 2012). Servant leadership is that kind of leadership style.

Although servant leadership is practiced in both nonprofit and for-profit organizations, little empirical research exists to examine servant leadership theory in an organizational setting (Pariss \& Peachey, 2013). No consensus of the definition of servant leadership exists among scholars (Focht \& Ponton, 2015; van Dierendonck, 2011). Greenleaf (1977), who coined the term servant leadership and is considered its grandfather, described servant leadership: "It begins with the natural feeling one wants to serve, to serve first. Then conscious choice brings one to aspire to lead" (p. 27). This lack of a clear definition of servant leadership has resulted in many conceptual frameworks and measurement tools to test servant leadership empirically (van Dierendonck, 2011). Nevertheless, despite this lack of consensus among scholars, servant leadership remains a viable, tenable leadership theory with the potential to transform organizations and individuals in positive directions (Parris \& Peachey, 2013).

Views on leadership behavior are changing because of recent demands for a more ethical and people-centered leadership style, particularly after the leadership scandals of Enron, WorldCom, Tyco, University of Illinois, University of Colorado, and UC Santa Cruz. Researchers have therefore suggested that servant leadership theory, with its focus on ethical and authentic leadership, may provide an answer to what organizations need (van Dierendock, 2011).

Many researchers have argued that servant leadership is distinct from other leadership theories. Although many other leadership theories partially or individually address areas such as honesty, integrity, morality, authenticity, people-centered leadership, and spirituality, these traits are combined under servant leadership theory (Dearth \& West, 2014; Sendjaya \& Cooper, 2010). Servant leadership is also unique among styles of leadership in its focus on the needs and desires 
of the followers. Servant leadership emphasizes the empowerment, growth, and personal development of the followers, with the focus on the needs of followers before the needs of the leader (Liden et al., 2015; Stewart, 2012). This emphasis stands in contrast to other leadership theories in which the focus is on the leader and the well-being of the organization rather than on the well-being of the followers (Jacobs, 2011; Rachmawati \& Lantu, 2014). This followeroriented attitude fosters an environment of strong relationships in which the followers are encouraged to become the best they can be for the good of the organization (van Dierendonck, 2011).

According to Greenleaf (1977), the servant leader is above all primus inter pares, Latin for first among equals. A servant leader does not exercise his authority to coerce followers to perform but rather uses persuasion. Servant leaders consider their power and authority as an opportunity to serve others, and as such, serving and leading become almost interchangeable (van Dierendonck, 2011). Furthermore, servant leaders find their fulfillment and motivation not in exercising power over their followers but in serving them and seeing them grow as persons (Letizia, 2014; Thompson, 2014). According to Greenleaf (1977), this commitment to service first is a key requirement of good leadership.

The principles, behaviors, and characteristics of servant leaders influence the effectiveness of the leader (Dearth \& West, 2014; Parris \& Peachey, 2013; Rachmawati \& Lantu, 2014; Thompson, 2014; van Dierendonck, 2011). An essential theme of servant leadership is building relationships (Buchen, 1998). Buchan (1998) argued that Greenleaf's (1977) model of servant leadership provided a new framework for institutions of higher education and its faculty. Buchan suggested this model for addressing the essential transformational needs of higher education.

Retaining students in online courses and sustaining a high level of student satisfaction is difficult (Cole et al., 2014; Croxton, 2014). This difficulty is the result of the sense of isolation that students experience when studying online (Rovai \& Downey, 2010; van de bunt-Kokhuis \& Sultan, 2013). Online students experience an absence of social presence, a sense of isolation, and a lack of interaction with the teacher and other learners (Rovai \& Downey, 2010; Reed \& Swanson, 2014; van de bunt-Kokhuis \& Sultan, 2013). As online education grows, the need for high-quality leadership among instructors grows as well. High-quality leadership that focuses on building relationships between teachers and students is needed (Huber \& Carter, 2014; Nyamboli, 2014).

Servant leadership is a style of leadership with the potential to improve student satisfaction and retention for online learning in higher education (Huber, 2014; van de Bunt-Kokhuis \& Sultan, 2012). Servant leadership is characterized by the qualities of "listening, forgiveness, empathy, humility, care for people and organization, healing of relationships, awareness, persuasion, courage, giving feedback, conceptualization, foresight, stewardship, authenticity, commitment to growth and empowerment of others, and building community" (van de Bunt-Kokhuis \& Sultan, 2012 , p. 2). These qualities have made servant leadership one of the five most discussed leadership theories in the current leadership literature (Nyamboli, 2014).

Existing research regarding servant leadership indicates a relationship between servant leadership and student satisfaction in an online educational setting. Many researchers (e.g., Bogler et al., 2013; Huber, 2014; Livingston, 2011; Nyamboli, 2014; Padron, 2012; van de Bunt-Kokhius \& Sultan, 2012) have investigated factors related to satisfaction among online students. However, research on the role of online instructors in relationship to student satisfaction, particularly in terms of the leadership style of the instructor, is more limited. Servant leadership style has the potential 
to improve student satisfaction with online education (Huber, 2014; van de Bunt-Kokhius \& Sultan, 2012). However, most existing research on servant leadership in higher education has focused on measuring the organizational level of servant leadership rather than on examining servant leadership characteristics within individual instructors (Jacobs, 2011; Nyamboli, 2015; Padron, 2012). These researchers used the Organizational Leadership Assessment (OLA) designed by Laub (1999). The OLA instrument used in these research studies was not designed to measure servant leadership on the individual leader level, rather, it was created as a tool to measure the organizational level of servant leadership on six key dimensions of servant-leadership (Laub, 1999). These six dimensions are: (1) Values People, (2) Develops People, (3) Builds Community, (4) Displays Authenticity, (5) Provides Leadership, and Shares Leadership (Laub, 1999).

Not all researchers have established a link between perceived servant leadership behaviors and student satisfaction in an online learning setting (Nayamboli, 2014), student satisfaction in a face-to-face classroom setting (Padron, 2012), or effective teaching (Jacobs, 2011). Padron (2012) researched a face-to-face classroom setting and found a negative correlation between student satisfaction and perceived servant leadership at the organizational level. In an investigation of 68 doctoral level students and 25 faculty and staff members (Nyamboli, 2014), no significant relationship was found between the students' perceptions of the organization level of servant leadership and satisfaction with e-learning $(r=.02, p=.88)$. Participants were assessed by completing the Organization Leadership Assessment and the Distance Education Learning Environment surveys (Nyamboli, 2014). The findings showed that online doctoral students were satisfied with their online learning experience and that the participants perceived a moderate level of servant leadership at the organizational level.

As shown in the above brief literature review, most of the research on servant leadership in higher education has focused on measuring the organizational level of servant leadership rather than on examining servant leadership characteristics of individual instructors (Jacobs, 2011; Padron, 2012). This gap in the literature is problematic because the organizational level and the individual level of servant leadership are inextricably intertwined, and both must be considered (Covey, 1998; Irving, 2005). No empirical studies were located in which the relationship between the individual servant leadership styles of online instructors and online student satisfaction with the instructor was evaluated. However, the evidence from the research on servant leadership at the organizational level suggests that the same positive relationship may be found at the individual level (Huber, 2014; Jacobs, 2011; Steele, 2010).

\section{Methods}

To evaluate the extent to which altruistic calling, emotional healing, wisdom, persuasive mapping, and organizational stewardship (Barbuto \& Wheeler, 2006) in an online instructor predicted student satisfaction (Tsai \& Lin, 2012), we developed the following research questions.

Q1. What is the relationship, if any, between online student perceptions of the instructors' altruistic calling leadership behavior and student satisfaction with the instructor?

Q2. What is the relationship, if any, between online student perceptions of the instructors' emotional healing leadership behavior and student satisfaction with the instructor?

Q3. What is the relationship, if any, between online student perceptions of the instructors' wisdom leadership behavior and student satisfaction with the instructor? 
Q4. What is the relationship, if any, between online student perceptions of the instructors' persuasive mapping leadership behavior and student satisfaction with the instructor?

Q5. What is the relationship, if any, between online student perceptions of the instructors' organizational stewardship leadership behavior and student satisfaction with the instructor?

Q6. To what extent do individual components of servant leadership (altruistic calling, emotional healing, wisdom, persuasive mapping, and organizational stewardship) in online instructors, as perceived by students, predict student satisfaction with the instructor?

\section{Sample}

To address the research questions, we sampled 155 online adult students enrolled at a community college setting in the south-central United States. All participants were 18 years of age or older. The community college site, which we selected for convenience, was a regionally accredited community college with an enrollment of approximately 6,166 students during the fall 2015 semester. Of these students, 1,028 had enrolled in only one online course during the semester. The participants completed the survey at the end of a 16-week general educational courses offered during the fall 2015 semester. Participants had little or no face-to-face contact with their instructors, and no background on servant leadership was provided to the survey participants.

From the overall sampling frame, 224, or $21.8 \%$, agreed to participate in the study. This percentage was consistent with the anticipated response rate of approximately $20 \%$ (Chang \& Krosnick, 2010; Messer \& Dillman, 2011; Petrovčič, Petrič, \& Lozar Manfreda, 2016). Although 224 students attempted the survey, only 155 completed all the questions needed for analysis.

\section{Measures}

We used two online survey instruments to collect data for the study: the SLQ and the SET.

SLQ. The SLQ (Barbuto \& Wheeler, 2006) is a 23-item inventory that assesses the extent to which leaders display servant-leadership qualities as conceptualized by Greenleaf (1978) and Spears (1998). Two versions of the questionnaire exist: the self-report or leader version, and the rater or follower version. We used the rater version of the SLQ to measure five components of servant leadership: altruistic calling, emotional healing, wisdom, persuasive mapping, and organizational stewardship. We measured all five variables on Likert-type scales, with values ranging from 1 (strongly disagree) to 5 (strongly agree). We calculated the score for each variable as the mean score for the respective subscale. The SLQ provided a way to conduct empirical research on servant leadership behavior with proven validity and reliability (Barbuto \& Wheeler, 2006; Guillaume et al., 2013). We did not include the self-report or leader (faculty) version of the SLQ in this study because the focus of the study was on measuring the students' perception of their online instructors' servant leadership behaviors.

SET. The SET (Tsai \& Lin, 2012) is a five-item self-report inventory designed to measure student satisfaction with online instructors. The instrument measured the scores on a Likert-type scale, with values ranging from 1 (strongly disagree) to 5 (strongly agree). We calculated the student satisfaction score as the mean score for the five items on the scale. 


\section{Procedure}

After we received Institutional Review Board (IRB) approval, we requested a list of the students' emails from the office of the Dean of Online Learning at the selected college. From this list, we contacted 1,028 participants through e-mail with an invitation to participate in the study. The email stated the reasons for conducting the study and included contact information, an online link to the survey, and the informed consent form? Students were given three weeks to respond to the invitation. To encourage more student participation in the study, students were given an opportunity to win one of five $\$ 50$ Amazon gift cards.

Among those invited to participate in the study, 155 provided informed consent and completed all survey questions necessary to compute the mean scores for each scale or subscale. When study participants declined to answer one or more survey questions needed to calculate a given variable, we omitted the entire record from the analysis. Thus, all the 68 surveys with missing data were omitted. There were two reasons for this decision. First, the authors of the instruments did not provide instructions for missing value replacement. Therefore, a process of missing value replacement may have invalidated the results. Second, missing value replacement with mean substitution should be used only if $10 \%$ or fewer of the components of a given scale are missing (Baraldi \& Enders, 2010; Karanja, Zaveri, \& Ahmed, 2013). Because all scale scores used in this study included only four or five items, even one missing item would have exceeded the number of permissible items omitted.

We provided a link in the email message to the participants for access to the online survey, which was hosted by SurveyMonkey. We sent two follow-up email reminders to participants to reach students who may have missed the earlier email invitations. Data collection ended after three weeks. We downloaded the data from the SurveyMonkey website directly into SPSS software for analysis.

\section{Results}

Among the 224 respondents to the survey, one declined to provide informed consent and was therefore omitted from the study. Among the remaining 223 respondents, 155 (69.5\%) answered all survey questions needed to compute the independent and dependent variables. With a sample size of 155 , the achieved power of the bivariate correlation was $96.9 \%$, and the achieved power of the multiple linear regressions was $97.2 \%$, showing a strong statistical power for the results.

We performed Fisher's exact tests to determine if the distributions of academic class, course requirements, ethnicity, age, or gender were different between those with and without complete data for the independent and dependent variables. There was no evidence to suggest a difference in academic class, course requirements, ethnicity, age, or gender between those who did and those who did not answer all survey questions required to evaluate the independent and dependent variables.

The majority of the sample consisted of freshmen and sophomores. Two-thirds of the participants were female, and $81.9 \%$ were Caucasian. Almost two-thirds of the participants were between the ages of 18 and 29. Table 1 shows the demographic distribution of the participants. 
The Relationship Between Instructor Servant Leadership Behaviors and Satisfaction with Instructors in an Online Setting

\begin{tabular}{|c|c|c|}
\hline Characteristic & $N$ & Percent \\
\hline \multicolumn{3}{|l|}{ Gender } \\
\hline Male & 50 & 32.3 \\
\hline Female & 104 & 67.1 \\
\hline Missing & 1 & 0.6 \\
\hline \multicolumn{3}{|l|}{ Age at time of survey } \\
\hline 18 to 29 & 100 & 64.5 \\
\hline 30 to 44 & 37 & 23.9 \\
\hline 45 to 59 & 17 & 11 \\
\hline 60 or older & 1 & 0.6 \\
\hline \multicolumn{3}{|l|}{ Ethnicity } \\
\hline Caucasian & 127 & 81.9 \\
\hline African-American & 12 & 7.7 \\
\hline Asian & 1 & 0.6 \\
\hline Hispanic & 7 & 4.5 \\
\hline Other & 7 & 4.5 \\
\hline Missing & 1 & 0.6 \\
\hline \multicolumn{3}{|l|}{ Class level } \\
\hline Freshman & 45 & 29 \\
\hline Sophomore & 43 & 27.7 \\
\hline Junior & 22 & 14.2 \\
\hline Senior & 18 & 11.6 \\
\hline Other & 27 & 17.4 \\
\hline \multicolumn{3}{|l|}{ Course requirement } \\
\hline Required for major & 86 & 55.5 \\
\hline Required for minor & 16 & 10.3 \\
\hline Other requirement & 26 & 16.8 \\
\hline Elective & 27 & 17.4 \\
\hline
\end{tabular}

Note. $N=155$.

Table 1. Demographic Distributions of Participants

We measured all servant leadership variables on a Likert scale, with values ranging from 1 (strongly disagree) to 5 (strongly agree). Mean scores for servant leadership ranged from 2.49 for emotional healing to 3.58 for altruistic calling (see Table 2). Because the student satisfaction score was not normally distributed, as shown by a histogram, we reported the median rather than the mean. The median student satisfaction score was 4.0.

\begin{tabular}{lcc}
\hline Variable & & \\
\hline Altruistic calling & 3.58 & $S D$ \\
Emotional healing & 2.49 & .90 \\
Wisdom & 3.50 & .83 \\
Persuasive mapping & 3.08 & .86 \\
Organizational stewardship & 3.29 & .81 \\
\hline
\end{tabular}

Note. $N=155$.

Table 2. Servant Leadership Style: Means and Standard Deviations 


\section{Assumptions for Spearman's correlation}

The only requirement for Spearman's rho is that the relationship between the two variables be monotonic, or linear, rather than curvilinear (Bishara \& Hittner, 2012; Hill \& Lewicki, 2007). We confirmed this assumption for the current study by inspecting scatterplots of all bivariate relationships being tested. The variables (altruistic calling, emotional healing, wisdom, persuasive mapping, organizational stewardship, and student satisfaction with the instructor) were all measured on an interval scale, which we treated in this study as a continuous measurement. Scatterplots showed no evidence to suggest the linearity assumption was violated. In addition, the scatterplots showed no evidence of outliers.

\section{Assumptions for multiple linear regression}

Before conducting the multiple linear regression, the data was examined to ensure that it met the assumptions of linearity, normally distributed errors, homoscedasticity, and the absence of multicollinearity. Scatterplots, histograms, and the variance inflation factor scores indicated that these assumptions were met.

\section{Bivariate Correlations}

We computed five bivariate correlations using Spearman's rho correlation statistic. The predictor variables were the mean scores for each of the five subscales of the SLQ: (a) altruistic calling, (b) emotional healing, (c) wisdom, (d) persuasive mapping, and (e) organizational stewardship. For all bivariate correlations, the outcome variable was the mean score for the SET. Table 3 shows the results of the bivariate correlations.

\begin{tabular}{lrc} 
Variable & $r_{s}$ & $p$ \\
\hline Altruistic calling & $.70<.001$ \\
Emotional healing & $.51<.001$ \\
Wisdom & $.70<.001$ \\
Persuasive mapping & $.69<.001$ \\
Organizational stewardship & $.67<.001$ \\
\hline
\end{tabular}

Note. $N=155$.

Table 3. Servant Leadership Style: Bivariate Relationships with Student Satisfaction

Significant positive relationships between student satisfaction and all servant-leadership scores examined, $p<.001$ were identified. Spearman's rho correlation coefficients ranged from .51 for emotional healing to .70 for altruistic calling and wisdom.

For the stepwise multiple linear regression analysis, the overall model was significant, $F(3,151)=83.8, p<.001, R^{2}=.63$ (see Table 4$)$. Three predictor variables (altruistic calling, persuasive mapping, and wisdom) contributed significantly to the model. 


\begin{tabular}{|c|c|c|c|c|c|}
\hline \multirow[b]{2}{*}{ Variable ${ }^{a, b}$} & \multicolumn{2}{|c|}{$\begin{array}{c}\text { Unstandardized } \\
\text { Coefficients }\end{array}$} & \multirow{2}{*}{$\begin{array}{c}\text { Standardized } \\
\text { Coefficients }\end{array}$} & \multirow[b]{2}{*}{$t$} & \multirow[b]{2}{*}{$p$} \\
\hline & $B$ & Std. Error & & & \\
\hline (Constant) & -.10 & .25 & & -0.41 & .68 \\
\hline Altruistic calling $^{\mathrm{c}}$ & .43 & .10 & .35 & 4.50 & $<.001$ \\
\hline Persuasive mapping ${ }^{\mathrm{d}}$ & .40 & .10 & .31 & 3.85 & $<.001$ \\
\hline Wisdom $^{\mathrm{e}}$ & .28 & .11 & .21 & 2.52 & .01 \\
\hline
\end{tabular}

a. Dependent variable: student satisfaction with the instructor

b. $F(3,151)=83.8, p<.001$; $R^{2}$ attributed to the total model $=.63$

c. $R^{2}$ attributed to altruistic calling $=.52$

d. $R^{2}$ attributed to persuasive mapping $=.09$

e. $R^{2}$ attributed to wisdom $=.02$

Table 4. Stepwise Multiple Regression Analysis Predicting Student Satisfaction with Instructor from Servant Leadership Scores

The $R^{2}$ values showed that altruistic calling was the most significant predictor of student satisfaction, explaining $52 \%$ of the total variance. Additionally, persuasive mapping explained an additional $8.5 \%$ of the total variance, and wisdom explained an additional $1.6 \%$. While the other two predictor variables (emotional healing and organizational stewardship) did not contribute significantly to the overall regression model.

\section{Discussion and Conclusions}

Researchers have established that servant leadership has the potential to influence student satisfaction in a positive direction (Huber, 2014; Jacobs, 2011; Letizia, 2014; Padron, 2012; Reed \& Swanson, 2014; Searle, 2011; van de bunt-Kokhuis \& Sultan, 2013). Servant leadership behaviors in traditional, hybrid, or online classroom settings have been associated with higher levels of student satisfaction (Ali \& Ahmad, 2011; Jacobs, 2011; Huber, 2014; Johnson, Aragon, \& Shaik, 2000; Nyamboli, 2014; Setliff, 2014). Servant leadership behaviors have also been positively correlated with related outcomes such as exemplary instruction (Setliff, 2014); teaching effectiveness (Drury, 2005; Metzcar, 2008), school climate (Black, 2010), and job satisfaction (Cerit, 2010; Irving, 2005; Laub, 1999; Shaw \& Newton, 2014; van Dierendock \& Nuijten, 2011).

The findings of the current study were congruent with existing research showing a correlation between servant leadership and student satisfaction. What distinguishes online learning from other traditional learning modalities is that the constraints of a set time and a set place affect the online learning milieu weakly or not at all (Nayamboli, 2014). We found a strong positive correlation between student satisfaction and five components of servant leadership in an online setting: altruistic calling, emotional healing, wisdom, persuasive mapping, and organizational stewardship (Barbuto \& Wheeler, 2006). These findings were consistent with earlier research showing that instructors who expressed personal consideration; who showed empathy and caring; and who offered intellectual stimulation, motivation, and inspiration tended 
to have more satisfied students (Bogler, Caspi, \& Roccas, 2013; Hazel et al., 2014; Ladyshewsky, 2013).

In the current study, the combined factors of altruistic calling, persuasive mapping, and wisdom predicted student satisfaction with instructors in an online environment. Similarly, Setliff (2014) indicated that of the five servant leadership behaviors, wisdom was the strongest predictor of exemplary instruction. Altruistic calling and persuasive mapping have also been correlated with exemplary instruction. Altruistic calling, emotional healing, wisdom, persuasive mapping, and organizational stewardship may create a positive environment in which student performance is enhanced (Huber, 2014; Jacobs, 2011; Letizia, 2014; Nyamboli, 2014; Padron, 2012; Reed \& Swanson, 2014; Searle, 2011; Setliff, 2014; van de bunt-Kokhuis \& Sultan, 2013).

While our results are not causal (we did not assess outcomes related to different pedagogical approaches), our results do imply that online students at a community college perceived the servant leadership behaviors of their online instructors within the virtual learning environment. This implication suggests that institutions of higher learning who wish for an increased level of student satisfaction within the online learning setting may find it beneficial to incorporate faculty trainings that help faculty members integrate servant leadership behaviors into their pedagogical approach to the online classroom. We recommend that these considerations focus on the servant leadership behaviors of altruistic calling, persuasive mapping, and wisdom.

Setliff (2014) suggested using the Servant Leader Development Model for Faculty by Antecedent, which was used for data collection and feedback regarding servant leadership behaviors (see Appendix A). In the current study, this model was adapted and modified for an online classroom setting based on the results of the current research. Based on this model, online instructors, administrators, and other stakeholders will be able to have ongoing feedback on servant leader behaviors and their application in an online classroom setting. Following is a discussion of the limitations for each research question.

\section{Limitations}

There were several limitations to this study. The study included only adult students who enrolled in a particular online class during the fall 2015 semester at a community college setting in the south-central United States. Expanding the scope of this research to other community colleges, 4-year public colleges, graduate programs, and private colleges would extend the generalizability of the findings. Another limitation was the self-report nature of the study. Students who responded to the follower version of the SLQ may have rated their instructors differently from the way the instructors would have rated themselves on the leader version of the SLQ.

This research was limited by the cross-sectional design. We were unable to observe changes in the relationship between servant leadership behaviors of online instructors and student satisfaction over an extended period ( $\mathrm{Lu}$ et al., 2013). Finally, 68 (30.5\%) of the respondents declined to answer all the survey questions needed to compute the independent and dependent variables, resulting in nonresponse bias. This nonresponse rate may limit the generalizability of the results to the population of interest.

\section{Future directions}

Ten years after its development, the SLQ (Barbuto \& Wheeler, 2006) has emerged as one of the leading measures of individual servant leadership behaviors (Setliff, 2014). However, most 
research on servant leadership theory in higher education has focused on the traditional classroom setting. There is a need to develop new instruments better suited for the online learning milieu.

Greenleaf (1977), who first introduced the construct of servant leadership, stated, "What I have to say comes from experience, my own and that of others, which bears on institutional reconstruction. It is a personal statement, and it is meant to be neither a scholarly treatise nor a how-to-do-it manual" (p. 49). Since 1977, servant leadership has lacked a unified theoretical framework. Little empirical research on servant leadership has been conducted with wide, substantive, and practical applications (Dean, 2014; Fotch \& Ponton, 2015; Parris \& Peachey, 2013; van Dierendonck, 2011; van Dierendonck et al., 2014). As such, researchers in this young field of servant leadership theory have ample challenges to produce empirical research that will further validate the use of servant leadership across diverse organizational settings (Noland \& Richards, 2015). Such research can provide further insights and understanding of this theory for future researchers and practitioners.

The current study has shown that the SLQ can be used in an educational setting, such as a community college. We recommend that this study be replicated in different settings, such as state universities, private colleges, graduate programs, and for-profit educational institutions. Such research may provide additional data on how servant leadership behaviors are related to student satisfaction with online learning and thus fill the existing gap in the literature for this area of study.

Replicating this study with a larger population — using the leader-rated version of the SLQ rather than the follower-rated version used in this study - may provide a different perspective on servant leadership behaviors and their relationship to student satisfaction. Scoring servant leadership behaviors from the perspectives of both instructors and students may provide a better indication of the factors related to online student satisfaction. The current study confirmed earlier findings on servant leadership behaviors in the classroom, but servant leadership theory stands in need of continual development toward a clearer definition and construct measurement (Noland \& Richards, 2015). Qualitative research involving interviews with students and faculty members may provide additional insights regarding the experiences of students and faculty members with servant leadership behaviors.

Based on the findings of the current study, we recommend a servant-leadership training model to prepare online instructors. This model, adapted from Setliff (2014), could be used to train online faculty members to develop their servant leadership behavior skills as a way of increasing student satisfaction with online learning.

\section{Conclusions}

The current study was the first in which the relationship between individual servant leadership behaviors and online student satisfaction was examined empirically. Additionally, the study was the first in which this relationship was tested at the level of the individual instructors rather than at the organizational level in an online learning setting. The results showed that individual servant leadership behaviors (altruistic calling, emotional healing, wisdom, persuasive mapping, and organizational stewardship) were positively correlated with student satisfaction. Three of these behaviors (altruistic calling, wisdom, and persuasive mapping) strongly predicted student satisfaction in combination. These findings provided evidence consistent with the current servant leadership literature, according to which levels of student satisfaction increased when 
instructors exhibited servant leadership behaviors in traditional, hybrid, or online classroom settings (Ali \& Ahmad, 2011; Jacobs, 2011; Huber, 2014; Paul \& Fitzpatrick, 2015; Setliff, 2014).

This study has empirically demonstrated the correlation of the individual servant leadership behaviors in the online classroom to student satisfaction. We recommend that servant leadership be an option for inclusion in faculty and staff training, curriculum development, and instructional environments, with a focus on the servant leadership behaviors of altruistic calling, persuasive mapping, and wisdom. Such training in servant leadership may be an answer to the quest for a new type of leadership in higher education required to meet the needs and the challenges faced by online learners (Huber, 2014; Nyamboli, 2014; van de Bunt-Kokhius \& Sultan, 2012). Servant teachers aim to help students maximize their personal potential by focusing primarily on the students' needs (Noland \& Richards, 2015). This new type of compassionate leadership can juxtapose digital technology and human feeling in the online learning classroom (van de BuntKokhius \& Sultan, 2012). 
The Relationship Between Instructor Servant Leadership Behaviors and Satisfaction with Instructors in an Online Setting

\section{References}

Allen, I. E., \& Seaman, J. (2016). Online report card: Tracking Online Learning in the United States. Retrieved form Babson Survey Research Group and Quahog Research Group website: http://onlinelearningsurvey.com/reports/ onlinereportcard.pdf

Ali, A., \& Ahmad, I. (2011). Key factors for determining students' satisfaction in distance learning courses: A study of allama iqbal open university. Contemporary Educational Technology, 2(2), 118-134.

Baraldi, A. N., \& Enders, C. K. (2010). An introduction to modern missing data analyses. Journal of School Psychology, 48(1), 5-37. doi:10.1016/j.jsp.2009.10.001

Barbuto, J. E., \& Wheeler, D. W. (2006). Scale development and construct clarification of servant leadership. Group \& Organization Management, 31(3), 300-26

Barnabas, A., Joseph, A., \& Clifford, P. (2010). The need for awareness of servant leadership in business schools. Academic Leadership (15337812), 8(2), 1-6.

Bishara, A. J., \& Hittner, J. B. (2012). Testing the significance of a correlation with non-normal data: Comparison of Pearson, Spearman, transformation, and resampling approaches. Psychological Methods, 17(3), 399-417. doi:10.1037/a0028087

Black, G. (2010). Correlational analysis of servant leadership and school climate. Catholic Education: A Journal of Inquiry \& Practice, 13(4), 437-466.

Blanchard, K., \& Miller, M. (2007). The higher plane of leadership. Leader to Leader, 2007(46), 25-30. doi:10.1002/1tl.253

Bogler, R., Caspi, A., \& Roccas, S. (2013). Transformational and passive leadership: An initial investigation of university instructors as leaders in a virtual learning environment. Educational Management Administration \& Leadership, 41(3), 372-392. doi:10.1177/1741143212474805

Bolkan, S., \& Goodboy, A. K. (2011). Behavioral indicators of transformational leadership in the college classroom. Qualitative Research Reports in Communication, 12(1), 10-18. doi:10.1080/17459435.2011.601520

Bolkan, J. (2013). Report: Students taking online courses jumps 96 percent over 5 years. Campus Technology. Retrieved from http://campustechnology.com/articles/ 2013/06/24/reportstudents-taking-online-courses-jumps-96-percent-over-5-years.aspx

Bowen, W.G. (2013). Walk deliberately, don't run, toward online education. The Chronicle of Higher Education. Retrieved from http://chronicle.com/article/Walk-Deliberately-DontRun/138109/

Buchen, I. H. (1998). Servant leadership: A model for future faculty and future institutions. The Journal of Leadership Studies, 5(1), 125-134.

Cerit, Y. (2010). The effects of servant leadership on teachers' organizational commitment in primary schools in Turkey. International Journal of Leadership in Education, 75(3), 301317. doi:10.1080/13603124.2010.496933 
Chang, L., \& Krosnick, J. A. (2010). Comparing oral interviewing with self-administered computerized questionnaires: An experiment. Public Opinion Quarterly, 74(1), 154-167.

Cole, M. T., Shelley, D. J., \& Swartz, L. B. (2014). Online instruction, e-learning, and student satisfaction: A three-year study. International Review of Research In Open \& Distance Learning, 15(6), 111-131.

Covey, S. R. (1998). Foreword. In L. C. Spears (Ed.), Insights on leadership: Service, stewardship, spirit, and servant-leadership (21-28). New York: John Wiley \& Sons.

Croxton, R. A. (2014). The role of interactivity in student satisfaction and persistence in online learning. Journal of Online Learning \& Teaching, 10(2), 314-324.

Dallal G. E. (2012). What do the coefficients in a multiple linear regression mean? Retrieved from http://www.jerrydallal.com/lhsp/regcoef.htm

Dearth, J., \& West, G. B. (2014). The use of servant leadership in the United Methodist church. Interdisciplinary Journal of Research on Religion. Retrieved from http://www.religjournal.com /pdf/ijrr10005.pdf

Dean, D. R. (2014). Servant leadership for higher education: Principles and practices. Review of Higher Education, 37(2), 274-277. Retrieved from http://search.proquest.com.proxy1.ncu.edu/docview/1465556898/fulltextPDF/668786A3 76864C35PQ/79?accountid=28180

Drury, S. (2005). Teacher as servant leader: A faculty model for effectiveness with students. Servant Leadership Research Roundtable, School of Leadership Studies at Regent University. Retrieved from http://www.regent.edu/acad/global/ publicationssl_proceedings/2005/drury_teacher_servant.pdf

Focht, A. \& Ponton, M. (2015). Identifying primary characteristics of Servant leadership: Delphi study. International Journal of Leadership Studies. Retrieved from http://www.regent.edu/acad/global/publications/ijls/new/vol9iss1/ 1-IJLS.pdf

Garcia, I. (2015). Emergent leadership: Is e-leadership importance in the quality of virtual education? (liderazgos emergentes: ¿es importante el e-liderazgo en la calidad de la educación virtual?). Revista Iberoamericana De Educación a Distancia, 18(1), 25-44.

Retrieved from http://search.proquest.com.proxy1. ncu.edu/docview/1649109292/fulltextPDF/AEBC2C0DAB544195PQ/1?accountid=28180

Greenleaf, R. K. (1977). Servant leadership: A journey into the nature of legitimate power and greatness. New York: Paulist Press.

Greenleaf, R. K. (1978). The servant leader. Westfield, IN: Greenleaf Center for Servant Leadership

Greenleaf, R.K. (1982). Teacher as Servant: A Parable. NJ: Paulist.

Gomez, D. (2013). Leadership behavior and its impact on student success and retention in online graduate education. Academy of Educational Leadership Journal, 17(2), 13-37. Retrieved from http://search.proquest.com.proxy1.ncu.edu/docview

$/ 1368612995$ ?accountid $=28180$ 
Guillaume, O., Honeycutt, A., \& Savage-Austin, A. R. (2013). The impact of servant leadership on job satisfaction. Journal of Business and Economics, 4(5), 444-448.

Hart, C. (2012). Factors associated with student persistence in an online program of study: A review of the literature. Journal of Interactive Online Learning, 11(1), 19-42.

Hazel, M., Crandall, H. M., \& Caputo, J. S. (2014). The influence of instructor social presence and student academic entitlement on teacher misbehaviors in online courses. Southern Communication Journal, 79(4), 311-326. doi:10.1080/1041794X.2014.914563

Hill, T. \& Lewicki, P. (2007). Statistics: Methods and Applications. StatSoft, Tulsa, OK.

Huber, R. L. (2014). Servant leadership, self-efficacy, and communities of inquiry in higher education online learning (Order No. 3623182). Available from ProQuest Dissertations $\&$ Theses Full Text. (1548333568). Retrieved from http://search.proquest.com.proxy1.ncu.edu/docview/1548333568/58B40E1F1D84EC1PQ /6? accountid=28180\#

Huber, R. \& Carter, H. (2014). Applying the servant leadership model to e-teaching. In T. Bastiaens (Ed.), Proceedings of E-Learn: World Conference on E-Learning in Corporate, Government, Healthcare, and Higher Education 2014 (pp. 880-887). Chesapeake, VA: Association for the Advancement of Computing in Education (AACE).

Irving, J. A. (2005). Servant leadership and the effectiveness of teams (Order No. 3173207). Available from ABI/INFORM Global; ProQuest Dissertations \& Theses Full Text. (305356267). Retrieved from http://search.proquest.com. proxy1.ncu.edu/docview /305356267/2D8ECD30D1D643C7PQ/ 1 ?accountid=28180\#

Jaccard, J., \& Daniloski, K. (2012). Analysis of variance and the general linear model. In H. Cooper, P. M. Camic, D. L. Long, A. T. Panter, D. Rindskopf, K. J. Sher, ... K. J. Sher (Eds.), APA handbook of research methods in psychology, Vol 3: Data analysis and research publication (163-190). Washington, DC, US: American Psychological Association. doi:10.1037/13621-008

Jacobs, K. (2011). Assessing the relationship between servant leadership and effective teaching in a private university setting. (Doctoral dissertation, Northcentral University). Retrieved from http://search.proquest.com.proxy1.ncu.edu/docview /908959989/13EA3653420 4B917C7F/1 ?accountid $=28180$

Johnson, S.S., Aragon, S. R., \& Shaik, N. (2000). Comparative analysis of learner satisfaction and learner outcome in online and face-to-face learning environments. Journal of Interactive Learning Research, 11 (1), 29-49.

Joo, Y., Joung, S., \& Kim, J. (2013). Structural Relationships among E-learners' Sense of Presence, Usage, Flow, Satisfaction, and Persistence. Journal of Educational Technology \& Society, 16(2), 310-324.

Johnson, A. C., \& Vishwanath, K. R. (2011). Servant professorship and its implications. International Journal of Education Research, 6(1), 135-146. 
Jones, B. M., Everard, A., \& McCoy, S. (2011). Distance education at the graduate level: A viable alternative. Contemporary Issues in Education Research (Online), 4(11), 9. Retrieved from http://search.proquest.com.proxy1.ncu.edu/docview /1418443722/E5A68BFEDA524F59PQ/1?accountid=28180\#

Joo, Y. J., Lim, K. Y., \& Kim, E. K. (2011). Online university students' satisfaction and persistence: Examining perceived level of presence, usefulness and ease of use as predictors in a structural model. Computers \& Education, 57, 1654-1664. http://dx.doi.org/10.1016/j.compedu.2011.02.008

Karanja, E., Zaveri, J., \& Ahmed, A. (2013). How do MIS researchers handle missing data in survey-based research: A content analysis approach. International Journal of Information Management,33(5), 734-751. doi:10.1016/j.ijinfomgt.2013.05.002

Kohle Paul, W., \& Fitzpatrick, C. (2015). Advising as servant leadership: Investigating student satisfaction. The Journal of the National Academic Advising Association, 35(2), 28-35.. doi:10.12930/NACADA-14-019

Kranzow, J. (2013). Faculty leadership in online education: Structuring courses to impact student satisfaction and persistence. Journal of Online Learning \& Teaching, 9(1), 131-139.

Ladyshewsky, R. K. (2013). Instructor presence in online courses and student satisfaction. International Journal for The Scholarship of Teaching \& Learning, 7(1), 1-23.

Laub, J. A. (1999). Assessing the servant organization: Development of the servant organizational leadership assessment (SOLA) instrument. (Doctoral dissertation, Florida Atlantic University). Retrieved from http://www.olagroup. com/Images/mmDocument/ Laub\%20Dissertation\%20Complete\%2099.pdf

Leroy, H., Palanski, M. E., \& Simons, T. (2012). Authentic leadership and behavioral integrity as drivers of follower commitment and performance. Journal of Business Ethics, 107(3), 255-264. doi:http://dx.doi.org/10.1007/s10551-011-1036-1

Letizia, A. (2014). Radical servant leadership: A new practice of public education leadership in the post-industrial age. Journal for Critical Education Policy Studies (JCEPS), 12(2), 175-199.

Liden, R. C., Wayne, S. J., Meuser, J. D., Hu, J., Wu, J., \& Liao, C. (2015). Servant leadership: Validation of a short form of the SL-28. The Leadership Quarterly,26(2), 254-269. doi:10.1016/j.leaqua.2014.12.002

Livingston, R. K. (2011). An investigation of transformational leadership in a virtual learning environment. (Doctoral dissertation, Capella University). Retrieved from http://search.proquest.com.proxy1.ncu.edu/docview/839860506/58723CE61CD94853PQ $/ 1$ ?accountid=28180\#

Lorenzo, G. (2012). A research review about online learning: Are students satisfied? Why do some succeed and others fail? What contributes to higher retention rates and positive learning outcomes? Internet Learning, 1(1), Fall 2012.

Lu, N., Han, Y., Chen, T., Gunzler, D. D., Xia, Y., Lin, J. Y., \& Tu, X. M. (2013). Power analysis for cross-sectional and longitudinal study designs. Shanghai Archives of Psychiatry, 25(4), 259-262. http://doi.org/10.3969/j.issn.1002-0829.2013.04.009 
The Relationship Between Instructor Servant Leadership Behaviors and Satisfaction with Instructors in an Online Setting

Mariano, D. G. (2013). The effectiveness of creating a sense of community in online learning with social awareness information. (73), ProQuest Information \& Learning, US. Retrieved from http://proxy1.ncu.edu/login?url= http://search.ebscohost.com/login.aspx?direct=true\&db=psyh\&AN=2013-99030211\&site=ehost-live

Messer, B. L., \& Dillman, D. A. (2011). Surveying the general public over the internet using address-based sampling and mail contact procedures. Public Opinion Quarterly, 75(3), 429-457. doi:10.1093/poq/nfr021

Metzcar, A. (2008). Servant leadership and effective classroom teaching. Ed. D. dissertation, Indiana Wesleyan University, United States -- Indiana. Retrieved from Dissertations \& Theses: Full Text. (Publication No. AAT 3344705)

Noland, A., \& Richards, K. (2015). Servant Teaching: An exploration of teacher servant leadership on student outcomes. Journal of the Scholarship of Teaching \& Learning, 15(6), 16-38. doi:10.14434/josotl.v15i6.13928

Nyamboli, R. N. K. (2014). Perceptions of organizational servant leadership and doctoral student satisfaction with e-learning (Order No. 3666806). Available from ProQuest Dissertations \& Theses Global. (1641109699). Retrieved from http://search.proquest.com.proxy1.ncu.edu/docview/1641109699?accountid=28180

Padron, J. (2012). Higher education leadership: Servant leadership and the effects on student satisfaction. (Doctoral dissertation, Argosy University). Retrieved from http://search.proquest.com.proxy1.ncu.edu/docview/1221263941/13EA35E68D26A10C D54/1 ?accountid $=28180$

Parris, D. L., \& Peachey, J. W. (2013). A systematic literature review of servant leadership theory in organizational contexts. Journal of Business Ethics, 113(3), 377-393. doi:10.1007/s10551-012-1322-6

Petrovčič, A., Petrič, G., \& Lozar Manfreda, K. (2016). The effect of email invitation elements on response rate in a web survey within an online community. Computers in Human Behavior, 56320-329. doi:10.1016/j.chb.2015.11.025

Pounder, J. (2014). Quality teaching through transformational classroom leadership. Quality Assurance in Education: An International Perspective, 22(3), 273-285. doi:10.1108/QAE-12-2013-0048

Rachmawati, A. W., \& Lantu, D.C. (2014). Servant leadership theory development \& measurement. Procedia - Social and Behavioral Sciences, 115, 387-393. http://dx.doi.org/10.1016/j.sbspro.2014.02.445

Reed, L. L., \& Swanson, A. (2014). Servant leadership: Innovative leader development in the online classroom and beyond. Developments in Business Simulation and Experiential Learning, 41.

Ren, X. (2010). How to practice servant leadership. Studies in Literature and Language, 7(1), 710. 
Rovai, A. P., \& Downey, J. R. (2010). Why some distance education programs fail while others succeed in a global environment. Internet \& Higher Education, 13(3), 141-147. doi:10.1016/j.iheduc.2009.07.001

Schreiner, L. A., \& Nelson, D. D. (2013). The contribution of student satisfaction to persistence. Journal of College Student Retention: Research, Theory And Practice,15(1), 73-111. doi:10.2190/CS.15.1.f

Searle, T. P. (2011) Servant leadership, hope, and organizational virtuousness. Journal of Leadership and Organizational Studies, 18(1), 107-117. doi: 10.1177/ 1548051810383863

Sendjaya, S., \& Cooper, B. (2010). Servant leadership behaviour scale: A hierarchical model and test of construct validity. European Journal of Work and Organizational Psychology, iFirst article. doi:10.1080/13594321003590549

Setliff, R. C., Jr. (2014). A study of student perceptions of exemplary instruction and servant leader behavioral qualities (Order No. 3617675). Available from ProQuest Dissertations $\&$ Theses Global. (1526012795). Retrieved from http://search.proquest.com.proxy1.ncu.edu/docview/1526012795/fulltextPDF/CA77CCC ABEEB48CFPQ/1?accountid=28180\#

Shaw, J., \& Newton, J. (2014). Teacher retention and satisfaction with a servant leader as principal. Education, 135(1), 101-106.

Spears, L. (1998). Tracing the growing impact of servant leadership. In L.C. Spears (Ed.), Insights on leadership: Service, stewardship, spirit, and servant leadership (1-12). New York: Wiley

Spears, L. (Ed.). (2005). Who is the servant-leader? The Servant Leader: The Newsletter of the Robert K. Greenleaf Center for Servant Leadership, 57, 2.

Steele, N. (2010). Three characteristics of effective teachers. Update: Applications of Research in Music Education, 28(2) 71-78. doi: 10.1177/8755123310361769

Stewart, T. (2012). Classroom teacher leadership: service-learning for teacher sense of efficacy and servant leadership development. School Leadership \& Management, 32(3), 233-259. doi:10.1080/13632434.2012.688741

Thompson, A. (2014). Fostering Growth and Development of Recovering Students in Higher Education Through Servant Leadership. Peabody Journal of Education (0161956X), 89(2), 244-257. doi: 10.1080/0161956X.2014.897101

Tsai, K. C., \& Lin, K. (2012). Rethink student evaluation of teaching. World Journal of Education, 2(2), 17-n/a. Retrieved from http://search.proquest.com.proxy1. ncu.edu/docview/1030090580/868DA742657844ABPQ/1?accountid=28180

van de Bunt-Kokhuis, S. \& Sultan, N. (2012). Servant-leadership: The online way! e-learning where community building is key. European Journal of Open, Distance and E-Learning, 1. Retrieved from http://www.eric.ed.gov/PDFS/EJ979595.pdf

van de Bunt-Kokhuis, S. B., \& Weir, D. (2013). Serving culturally diverse e-learners in business schools. Multicultural Education \& Technology Journal, 7(1), 17-45.

doi:http://dx.doi.org/10.1108/17504971311312609 
van Dierendonck, D. (2011). Servant leadership: A review and synthesis. Journal of Management, 37(4), 1228-1261. doi:10.1177/0149206310380462

van Dierendonck, D., \& Nuijten, I. (2011). The servant leadership survey: Development and validation of a multidimensional measure. Journal of Business and Psychology, 26, 249267.

van Dierendonck, D., Stam, D., Boersma, P., de Windt, N., \& Alkema, J. (2014). Same difference? Exploring the differential mechanisms linking servant leadership and transformational leadership to follower outcomes. The Leadership Quarterly, 25(3), 544562. doi: http://dx.doi.org/10.1016/j.leaqua.2013.11.014

Wheeler, D. W. (2012). Servant leadership for higher education: Principles and practices. San Francisco, CA: Wiley

Woodall, T., Hiller, A., \& Resnick, S. (2014). Making sense of higher education: students as consumers and the value of the university experience. Studies in Higher Education, 39(1), 48-67. doi:10.1080/03075079.2011.648373

Xu, D., \& Jaggars, S. S. (2011). The effectiveness of distance education across Virginia's community colleges: Evidence from introductory college-level math and English courses. Educational Evaluation and Policy Analysis, 33(3), 360-377.

doi:10.3102/0162373711413814 
The Relationship Between Instructor Servant Leadership Behaviors and Satisfaction with Instructors in an Online Setting

Appendix A:

Integrated Servant Leader Development Model: Antecedent and Demonstrated Behavior

\begin{tabular}{|c|c|c|}
\hline Antecedent & Demonstrated behavior & Source \\
\hline \multirow[t]{5}{*}{$\begin{array}{l}\text { Altruistic } \\
\text { calling }\end{array}$} & $\begin{array}{l}\text { Willing to provide extra time to help students understand the } \\
\text { materials }\end{array}$ & SI \\
\hline & Encourages students to ask questions without a sense of stress & SI \\
\hline & Views teaching as a special calling, not a job & SIPG \\
\hline & Is a source of positive energy & SIPG \\
\hline & Believes success is measured by the success of students and peers & SIPG \\
\hline \multirow[t]{3}{*}{$\begin{array}{l}\text { Emotional } \\
\text { healing }\end{array}$} & $\begin{array}{l}\text { Willing to provide listening ears and a safe environment for the } \\
\text { students when they face personal trauma }\end{array}$ & SI \\
\hline & Encourages students to share their feelings regarding the course & SI \\
\hline & $\begin{array}{l}\text { Provides a meaningful input regarding mending the hard feelings } \\
\text { students face }\end{array}$ & SI \\
\hline \multirow[t]{6}{*}{ Wisdom } & Develops and creates "teachable moments" & SI \\
\hline & Creates a conducive learning environment & SI \\
\hline & Surveys the students' understanding of prior information & SI \\
\hline & $\begin{array}{l}\text { Clearly describes the objectives of the day's material and how it } \\
\text { builds upon prior learning }\end{array}$ & SI \\
\hline & $\begin{array}{l}\text { Uses various media to add depth, contrast, and context effectively } \\
\text { to illuminate and amplify salient points }\end{array}$ & SI \\
\hline & $\begin{array}{l}\text { Uses multimedia to bring outside experts into the online } \\
\text { classroom. }\end{array}$ & SI \\
\hline \multirow{6}{*}{$\begin{array}{l}\text { Organiza- } \\
\text { tional } \\
\text { steward- } \\
\text { ship }\end{array}$} & Develops and communicates positive regard for the organization & SIPG \\
\hline & $\begin{array}{l}\text { Describes connections with other organizations and the } \\
\text { community at large }\end{array}$ & PG \\
\hline & Emphasizes the social importance of group involvement & SIPG \\
\hline & Describes and communicates the importance of service to others & SIPG \\
\hline & Describes and demonstrates wise stewardship & SIPG \\
\hline & Emphasizes that each person must take responsibility & SIPG \\
\hline \multirow{7}{*}{$\begin{array}{l}\text { Persuasive } \\
\text { mapping }\end{array}$} & Seen as actively involved in student issues & SIPG \\
\hline & Has the ability to discuss the importance of direction with students & SI \\
\hline & $\begin{array}{l}\text { Has the ability to motivate students to perform at their highest } \\
\text { level }\end{array}$ & SI \\
\hline & $\begin{array}{l}\text { Has the ability to communicate in a fashion that inspires others to } \\
\text { follow }\end{array}$ & SIPG \\
\hline & Has the ability to follow a rational moral compass & SIPG \\
\hline & $\begin{array}{l}\text { Has the ability to obtain consensus through a highly developed } \\
\text { interpersonal skill set }\end{array}$ & $\mathrm{PG}$ \\
\hline & Is seen as one who can reduce confrontation & PG \\
\hline
\end{tabular}


Note. $\mathrm{SI}=$ student instructor review. $\mathrm{PG}=$ peer group review. $\mathrm{SIPG}=$ student instructor review and peer group review. Adapted from "A study of student perceptions of exemplary instruction and servant leader behavioral qualities,” (pp. 62-63) by Richard C. Setliff, Jr., 2014, Ph.D. dissertation, Indiana State University, Terre Haute, Indiana. Retrieved from Dissertations \& Thesis: Full Text. (1526012795). Used with permission. 
The Relationship Between Instructor Servant Leadership Behaviors and Satisfaction with Instructors in an Online Setting 